Marquette University Law School

Marquette Law Scholarly Commons

Faculty Publications

Faculty Scholarship

$1-1-2011$

\title{
Wisconsin Supreme Court and Legislative History
}

Patricia A. Cervenka

Marquette University Law School, patricia.cervenka@marquette.edu

Follow this and additional works at: http://scholarship.law.marquette.edu/facpub

Part of the Law Commons

Publication Information

Patricia A. Cervenka, Wisconsin Supreme Court and Legislative History, 30 Legal Reference

Services Q. 141 (2011). This is an electronic version of an article published in Legal Reference

Services Quarterly. Legal Reference Services Quarterly is available online at:

http://www.tandfonline.com/doi/abs/10.1080/0270319X.2011.585330.

\section{Repository Citation}

Cervenka, Patricia A., "Wisconsin Supreme Court and Legislative History" (2011). Faculty Publications. Paper 502.

http://scholarship.law.marquette.edu/facpub/502

This Article is brought to you for free and open access by the Faculty Scholarship at Marquette Law Scholarly Commons. It has been accepted for inclusion in Faculty Publications by an authorized administrator of Marquette Law Scholarly Commons. For more information, please contact 


\section{Wisconsin Supreme Court \& Legislative History}

Professor Patricia A. Cervenka, Director of the Marquette University Law Library; Eckstein Hall, 1215 West Michigan Avenue; Milwaukee, Wisconsin 53201. Research and editing assistance provided by Marquette Law Library Reference Librarians: Julia Jaet and Lois O’Brien.

Legislative History has been directly mentioned over 1800 times in the body of Wisconsin Supreme Court opinions. In 1927, the Wisconsin Legislature established the Legislative Reference Bureau to maintain files of drafting records for each proposed bill. Since the late 1990's the files are available electronically making the information more accessible to lawyers appearing in Wisconsin courts.

\section{Brief Description of State Legislative Process}

The Wisconsin Legislature is comprised of two houses: senate and assembly. Each house sets the rules for its proceedings, but is directed by the constitution as to the opening words of each act; that every law is enacted by bill; and that no law is in force until it is published. ${ }^{1}$ The Wisconsin Statutes define the number of legislators, the date for convening sessions in each odd-numbered year, as well as legislative committees, legislative service agencies and the regulation of lobbying activities. ${ }^{2}$

Each statute that is enacted must begin with a bill. Bills are usually introduced by a legislator or by one of the legislative committees. The Joint Committee on Finance introduces the governor's budget bill. Budget bills can be several hundred pages and contain many statutory amendments. The statutory amendments are usually in numerical order by statute so particular amendments can be found with careful reading.

\footnotetext{
${ }^{1}$ Wis Const, art. IV, § 17.

${ }^{2}$ Wis. Stat. $\$ 13.01$ et seq. (2009-2010).
} 
A legislator or the legislative council requests a draft of a bill to be written by a member of the Legislative Reference Bureau, one of the legislative service agencies. The bill is introduced in one of the houses and must be passed after all readings and procedures of the body before being sent to the other house to undergo its readings and procedures. When a bill has passed both houses, it is sent to the Legislative Reference Bureau for enrolling the final text before being sent to the governor. The governor periodically calls for bills that have been passed and has six days to sign, veto, or partially veto the bill. Two-thirds of each house must vote to override the governor's veto or partial veto.

The Legislative Reference Bureau (LRB) was created in 1901 and was given bill drafting responsibilities in $1907 .^{3}$ The LRB provides nonpartisan, confidential bill drafting, research and library services to the legislature. The LRB publishes each legislative act and produces the bound volumes of all session laws. The LRB publishes the Blue Book, the comprehensive guide to Wisconsin government, the Index to the Bulletin of the Proceedings of the Wisconsin Legislature, and maintains the collection of drafting records for all bills beginning with 1927.

\section{History of Usage of State Legislative Histories}

The Wisconsin Supreme Court has debated extensively about how legislative history may be used when interpreting statutes. In a 1996 article, the author stated that "...there are certain important idiosyncrasies litigators should be aware of when arguing in the Wisconsin state courts." ${ }^{4}$ Dortzbach describes the various theories of the

\footnotetext{
${ }^{3}$ Wis. Stat. $§ 13.92$ (2007-2008) listing duties and procedures for the LRB.

${ }^{44}$ Kenneth R. Dortzbach, Legislative History: the Philosophies of Justices Scalia and Breyer and the use of Legislative History by the Wisconsin State Courts, 80 Marq. L. Rev. 161, 201-219 (1996-1997).
} 
use of legislative history in the Wisconsin Supreme Court. In particular, he discusses cases highlighting the plain meaning rule, the alternative plain meaning rule and the use of legislative history to reinforce the meaning of a statute that is not deemed ambiguous.

The use of legislative history has not abated since the 1996 article. Using a Lexis search of the Wisconsin Supreme Court cases database in November, 2008, this writer found that in the last twelve years, more than 600 cases used the phrase legislative history even if the justices were only stating that researching the legislative history affirmed the fact that the statute had a plain meaning. Focusing on those 600 cases showed that 65 cases mentioned the drafting records, 83 mentioned the analysis by the Legislative Reference Bureau, and more than 30 mentioned revisions to a bill as helping to understand the statute at hand.

In 2004 the Wisconsin Supreme Court issued an opinion that addressed both ideas of refraining from using (majority opinion) and using (concurring opinion) legislative history. ${ }^{5}$ The majority and concurring opinions cited many different cases on legislative interpretation. The issue before the court was the meaning of the word "refuse" as it related to whether the district attorney had refused to prosecute the plaintiff. If the prosecutor had refused, then the secondary action kicked in and the circuit judge could authorize the filing of the complaint. In the majority opinion, Justice Sykes uses a variety of authorities that address statutory construction to support points

\footnotetext{
${ }^{5}$ Kalal v. Circuit Court for Dane County, 2004 WI 58, 681 N.W.2d 110 (2004).
} 
for not using legislative history in reaching a decision. ${ }^{6}$ She also cites a number of cases that have used the thought that "If this process of analysis yields a plain, clear statutory meaning, then there is no ambiguity, and the statute is applied according to this ascertainment of its meaning." "What is clear is that Wisconsin courts ordinarily do not consult extrinsic sources of statutory interpretation unless the language of the statute is ambiguous. $^{\prime \prime}$

The Chief Justice, in her concurring opinion, discusses the history of how the court had previously used legislative history in an inconsistent manner and then makes her arguments why legislative history should be used. Not only did the Chief Justice make an argument for using legislative history, but she set out a "non-exhaustive list of thirteen items that may be used for legislative history purposes that have been and will be helpful in interpreting a statute." ${ }^{\prime 9}$ Chief Justice Abrahamson listed non-statutory provisions, historical notes for each statute, the Legislative Reference Bureau's analysis, judicial council materials, joint legislative council materials; legislative committee records; records of special legislative committees, bill drafting records; legislative journals, Bulletin of Proceedings; Governor's Study Committees; Governor's Veto messages, and Cases previously before the court interpreting the same statute In addition, the Chief Justice describes the item's origin and states some of the locations where such material can be found in various libraries and websites around the state.

\footnotetext{
${ }^{6}$ Id., ๆๆ 36- 57, 658-670, 121-127.

${ }^{7}$ Bruno v. Milwaukee County, 2003 WI 28, ๆ20, 660 N.W.2d 656, 662.

${ }^{8}$ Kalal, ๆ 50, 666.

${ }^{9}$ Kalal, ๆๆ70-69, 678-679.
} 
The Chief justice does not state any precise weight that should be given to each piece, nor does she suggest that she has listed the items in rank order.

A sampling of the 2008 Wisconsin Supreme Court cases continue to show the variety of ways legislative history is used. Sands $v$. Whitnall ${ }^{10}$ reiterates ideas about the use of legislative history established in the Kalal opinion. The majority opinion in Richards v. Badger Mutual Insurance ${ }^{11}$ discusses legislative history options when dealing with an ambiguous statute. The majority opinion in State v. Grunke ${ }^{12}$ uses the analysis by the Legislative Reference Bureau, and the dissent uses the drafter's note ${ }^{13}$ in the drafting records to establish purpose for the statute. The concurring opinion in Watton v. Hegerty ${ }^{14}$ lists the use of legislative history as one of the considerations in determining the meaning of a statute. The dissent in State v. Beaver Dam ${ }^{15}$ examines special committee reports.

\section{Primary Sources - Description and availability}

Bulletin of Proceedings of the Wisconsin Legislature: The bulletin is generally issued weekly during legislative sessions, but less often during the times the committees are at work. It provides a record of the actions taken by both houses and can be accessed by subject, author, and bill number indexes. The online version has the bill histories back to 1995 and can

\footnotetext{
${ }^{10}$ Sands v. Whitnall, 2008 WI 89, ๆ15, 754 N.W.2d 439, 445 (2008)

${ }^{11}$ Richards v. Badger Mutual Insurance, 2008 WI 52, ๆ१20-30; 749 N. W. 2d 581, 587-590 (2008)

12 State v. Grunke, 2008 WI 82, ๆๆ33-35m , 752 N.W.2d 769, 778-779 (2008)

${ }^{13}$ Id. At 9 १153-57, 782 (2008)

${ }^{14}$ Watton v. Hegerty, 2008 WI 74, ๆ१41-42, 751 N.W.2d 369, 384 (2008)

${ }^{15}$ State v. Beaver Dam, 2008 WI 90, ๆๆ177 - 199, 752 N.W. 2d 295, 332-336 (2008)
} 
This is an electronic version of an article published in Legal Reference Services Quarterly. Legal Reference Services Quarterly is available online at: http://www.tandfonline.com/doi/abs/10.1080/0270319X.2011.585330.

be found by accessing the Wisconsin Legislature page at best is is this one;

$\underline{\text { http://www.legis.state.wi.us/rsb/Statutes.html }}$

http://nxt.legis.state.wi.us/nxt/gateway.dll/?f=templates\&fn=default.htm

Drafting records: "Drafting records are an administrative record of the bill drafting process...The drafting record is primarily designed to document that a bill has been drafted by the LRB in accordance with the instructions of a member of the legislature, and to facilitate the drafting of similar or identical proposals in the future." ${ }^{16 \prime \prime T h e ~ L e g i s l a t i v e ~ R e f e r e n c e ~ B u r e a u ~ h a s ~}$ been directed to maintain a collection of the written materials associated with a particular bill, resolution or joint resolution since 1927. Drafting records are organized by session year and act (or chapter) number. Drafting records may include many but not all of the following items: enrolling instructions, procedural history, request sheet, correspondence and background information; copy of bill and earlier drafts, drafter's note; amendments, prior bills, and constitutional amendments. ${ }^{17}$

The legislative reference bureau maintains the drafting records from 1927 - 1997 on microfiche and have posted the files from 1997 to date at http://www.legis.wisconsin.gov/w3asp/documents/drafting files.aspx . The files are also available at the Wisconsin State Law Library, the Wisconsin State Historical Society, Marquette Law Library, Milwaukee Public Library and the University of Wisconsin Law Library. They are maintained as CD-ROM files since 1999 in each of those places. The University of Wisconsin Law Library has the electronic files on their website at http://library.law.wisc.edu/eresources/draftingrecords/.

\footnotetext{
${ }^{16}$ Wisconsin Briefs 06-10, July 2006.

${ }^{17}$ Id at $10-12$.
} 
Fiscal estimates: Since 1953 each bill affecting revenue or expenditures must include a fiscal estimate about its impact.

Joint Legislative Council Materials: JLC, begun in 1947, establishes special committees made up of both legislators and interested citizens to study various problems of state and local government. The committees may draft proposals and submit them to the JLC if it wants matters introduced into the Legislature. The JLC must approve the drafts before they can be introduced as JLC bills. The study committees are listed on the web site from 1948 forward. Links to the publications are on the web site from 1998 forward. http://www.legis.state.wi.us/lc/committees/jointcouncil/index.htm

Judicial Council Materials: The legislature created the Judicial Council in 1951 to observe courts rules and procedures and to make recommendations that would promote a speedy determination of litigation on the merits. ${ }^{18}$ Materials may be found in print at the Wisconsin State Law Library, and at the website http://www.wicourts.gov/about/committees/judicialcouncil/index.htm .

Laws of Wisconsin: print version of the Wisconsin session laws. Since 1983 each law passed is called an act. Prior to 1983 each law passed was called a chapter. Each act has the bill number, date of enactment and the date of publication printed at the head of the act. The effective date of statutes is the day after the date of publication so each of those dates have significance for research projects. The bills are available back to 1989 at http://nxt.legis.state.wi.us/nxt/gateway.dll?f=templates\&fn=default.htm\&d=enrolled05\&jd=to $\underline{\mathrm{p}}$

\footnotetext{
${ }^{18}$ Wis. Stat. $\S 758.13(2009-2010)$
} 
Legislative Reference Bureau Analysis: Part of LRB's service includes preparing a plain language analysis describing the ramifications of the bill becoming law since $1967 .{ }^{19}$ The analysis is inserted in the first page of the bill. One caveat is that the paragraph of analysis is not changed should the bill be amended by one or both houses so it should only be used in connection with the language of the originally proposed bill.

Special Legislative Committees Records: Materials are available at the Legislative Council's website. Legislative committees do not keep verbatim transcripts of hearings, but do keep records of those who testified or any printed information submitted to the committee.

Wisconsin Statutes and Annotations: Title of the official codified arrangement of the Wisconsin Statutes published by the state. The history line following the statute gives the information about creation and amendments from 1971 forward. The case annotations were added in 1971. Prior to 1970, the history line information and the case annotations were published in a volume called Wisconsin Annotations. The online version is found at the state website, http://www.legis.wisconsin.gov/rsb/preface.html. Lexis and Loislaw show the same history line information as does the official printed version of the statutes.

West's Wisconsin Statutes Annotated, the unofficial statutory compilation, combines all the historical information about creation and amendments of each statute in the historical references at the end of each statute. The same is true for the Westlaw version.

\section{Other Sources}

\footnotetext{
${ }^{19}$ Wis. Stat. $113.92(1)(b) 2(2009-2010)$.
} 
- Wisconsin Blue Book, 2009-10. Compiled by the Wisconsin Legislative Reference Bureau for each legislative session. http://www.legis.state.wi.us/lrb/pubs

- Researching Legislative History in Wisconsin, by Michael J. Keane.

Madison: Wisconsin Legislative Reference Bureau, 2006 [Wisconsin Brief 06-10.] http://www.legis.state.wi.us//rb/pubs/wb/06wb10.pdf

- "How a Bill Becomes a Law," State of Wisconsin 2003-2004 Blue Book, 253-257. Compiled by the Legislative Reference Bureau. Madison: Wisconsin Legislative Reference Bureau, 2003. http://www.legis.state.wi.us/lrb/bb/03bb/253-257.pdf

- "How to Find Resources Relevant to Legislative History Research on Wisconsin Laws," by A. Peter Cannon. 1997 State Bar of Wisconsin Midwinter Convention [Program materials], v. II, 459-467.

- "Judicial Interpretation of Legislative Intent and Legislative History Documents," by N. Patrick Crooks. 1997 State Bar of Wisconsin Midwinter Convention [Program materials], v. II, 481-488.

- "Legislative History: The Philosophies of Justices Scalia and Breyer and the Use of Legislative History by the Wisconsin State Courts," by Kenneth R. Dortzbach. 80 Marquette Law Review 161-225 (1996-1997).

- "Researching Legislative Intent: Documentation Available Through the Wisconsin Legislative Council Staff," by Ronald L. Sklansky. 1997 State Bar of Wisconsin Midwinter Convention [Program materials], v. II, 471-479. 
This is an electronic version of an article published in Legal Reference Services Quarterly. Legal Reference Services Quarterly is available online at: http://www.tandfonline.com/doi/abs/10.1080/0270319X.2011.585330.

\section{Contact Information \\ Wisconsin State Law Library}

http://wsll.state.wi.us/

120 Martin Luther King Jr. Blvd, 2nd floor

Madison, WI 53703

1-800-322-9755

TTY: 1-800-947-6644

Reference: 608-267-9696, email wsll.ref@wicourts.gov

Circulation: 608-266-1600

\section{Wisconsin Historical Society}

816 State Street

Madison, WI 53706

608- 264-6400

http://www.wisconsinhistory.org/

\section{Legislative Research Services \\ Wisconsin Legislative Reference Bureau}

http://legis.wisconsin.gov/LRB/

One East Main Street

Suite 200

Madison, WI 53703

Reference (608) 266-0341

LRB.Reference@legis.wisconsin.gov

Library 608-266-7040

LRB.Library@legis.wisconsin.gov 